\title{
DEVELOPMENT OF PUBLIC DEBT IN THE SLOVAK REPUBLIC AND THE RISKS OF ITS DEEPENINING
}

\author{
Eleonóra Matoušková \\ University of Economics in Bratislava, Slovak Republic
}

The problem of over-indebtedness began to manifest itself significantly in the Euro area in 2009. Permanent government deficits and the global financial crisis have increased public debt in many, especially the southern Euro area countries, well above the Maastricht criterions. The Slovak Republic is not one of the countries with disproportionaly high debt, but in the era of its autonomy, it had to deal with three periods when the debt was increasing. It was a period of transformation of the economy from centrally managed to market economy after 1993, a period of economic recession due to the global financial and economic crisis and the current coronavirus pandemic, accompanied by a deep economic downturn. The need to tackle a number of inadequate social inequalities is also puttig pressure on the public finances. The aim of this article is to assess development of public debt in Slovakia and to draw attention to the risks of its deepening. Slovakia achieved relatively high levels of economic growth. These periods have not been sufficiently used to reduce public debt, which currently accounts for $48 \%$ of GDP. While its share to GDP is falling, the absolute volume of debt is increasing. Economic consequences of the current global coronavirus pandemic will cause further growth in public debt. Slovakia did not take enough opportunity in good times to prepare for the crisis period.

Keywords: public debt, state budget, revenue, expenditure

\section{Introduction}

Slovakia has never been one of the countries with disproportionately high public debt. However, since the creation of the independent Slovak Republic in 1993, the general government budget has never been reached. Public debt deepened further at the time of the Great Recession, as in many other countries in the world. The government has therefore developed the Stability Program of the Slovak Republic for the years 2017-2020 in order to achieve a balanced state budget and reduce public debt.

The objective of this article is to assess developments in the Slovak Republic in the field public finances and to draw attention to the risks of deepening public debt at present. For the reference period, we set the period 2002 to 2019 with a view to 2020 .

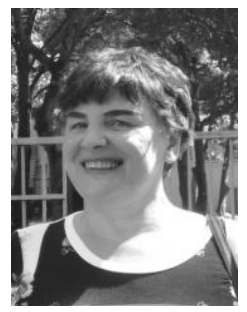

\section{Eleonóra Matoušková}

Ing., $\mathrm{PhD}$, works as Assistant Professor in the Department of Economic Theory at the University of Economics in Bratislava, Slovak Republic

Research interests: business cycle, economic policy, heterodox economics

E-mail: eleonora.matouskova@euba.sk 


\section{DEVELOPMENT OF PUBLIC DEBT IN THE SLOVAK REPUBLIC}

Years 2002-2008 were years of high growth of the Slovak economy. This growth has been interrupted by the global financial and economic crisis. After its overcoming, economic growth has restarted and thus created a precondition for reduction of public debt. Ambition was to achieve a balanced state budget by 2019 at the latest.

\section{Theoretical view of the issue of public debt}

The use of the state budget to stabilize the economy means that expenditure and revenue will not always be equal. In the event of a recession, the government has reasons to cut taxes or increase expenditure. However, by reducing tax revenues (or increasing expenditure), the government will cause a deficit. It comes at a time when the government has to borrow funds to pay for expenses that exceed tax revenues. Governments thus accumulate public debt (Schiller, 2004).

According to Rothbard, government loans are taking resources from the private sector twice. Once, when a loan is granted and private savings become a source of government spending, and then again, when the government is taxing entities or conducting inflation or borrowing again to raise money to pay off its debt. Transfer of resources from private producers to the government also occurs when state bonds are purchased (Rothbard, 1993).

What is important is how the loan is used. Productive consumption in the form of successful investments in the entrepreneurship or enhancement of human capital is a prerequisite for increasing productivity and growing future incomes. Debt sustainability also depends on real market interests and economic performance of the country (Karpiš, 2015).

High public debt can be eliminated in several ways. One of them is high economic growth. This through high employment and rising asset prices will increase the state's revenues. There will be a decrease in absolute debt relative to the size of the economy. It is a sufficient rate of economic growth that has allowed advanced economies to grow out of debt. The second way to reduce debt is to save. In the event of a growing economy, the government will limit the state's expenditure by equal to income. The more radical fiscal policy is to generate a budget surplus. Debt can also be removed by default when the state refuses to continue repaying its liabilities, mostly selectively to foreign creditors. In such a case, the state's representatives are seeking an agreement in which creditors forgive part of the net present value of the debt. The debt may be reduced either by excusing interest, part of the principal or only by extending the repayment schedule. Another option is to cause price inflation by increasing the amount of money in the economy. In the case of the last option to reduce debt, the central bank will force commercial banks, insurance companies and pension funds to invest the savings of the population in the public debt (Karpiš, 2015).

Krugman argues that the fear of budget deficits raises particular fears of an attack by speculative investors who, at the moment, when they lose confidence in monetary and fiscal policy, they sell out government bonds cheaply. This will drive up the price at which the state borrows. According to him, the market does not give proponents of fiscal rigor to be right. Because the price at which the state borrows is very law at the moment. Adjusted for inflation is even negative. Investors actually pay the government to keep their assets safe. These are long-term interest rates, therefore the market shows that investors do not foresee any major problems in the coming years (Krugman, 2012).

Roubini \& Mihm (2013) also point to the possibility of monetizing the debt. Central banks can start printing new money. This will cause inflation, reduce the real value of debt 
and transfer wealth from creditors to the government. At the same time, inflation reduces the real value of private liabilities, such as fixed rate mortgages, and also increases the nominal value of real estate and other assets. The public and private sectors will thus get out of debt. However, the problem may be controlling inflation. This will put central banks off their credibility. In the case of short-term and floating-ratedebt, the inflation-using debt solution would be ineffective. The expected rising inflation would mean that the maturity of these liabilities would be extended at higher interest rates. These rates would keep pace with inflation (Roubini \& Mihm, 2013).

The view that inflation will gradually erase debt is, according to the International Monetary Fund (IMF), wrong. Inflation will only cause further depreciation of the currency, which overprices the import of goods. Even if wages will be doubled, the price of the commodities that we buy for them will also rise, so we will not achieve such a return. Inflation will also cause the rise of interest rates, so debt repayment will become a greater financial burden. Wage increases will also increase the state's social and health costs. In order to be able to finance this all, governments will be forced to borrow more and thus increase the public debt. According to the IMF, inflation would reduce the growth of the debt-to-GDP ratio by less than a quarter. So a substantial portion of the debt would remain. The only real way is to spend less and save more (Maxton, 2011).

\section{Development of revenue and expenditure of the state budget}

In the aftermath of the financial crisis, especially in the period 2014-2018, the Slovak economy achieved high values of economic growth. The average rate of economic growth was $3.6 \%$ and the unemployment rate fell from $12.3 \%$ in 2014 to $5 \%$ in 2018 . It was a very favorable period for the government to no longer create budget deficits, but on the contrary, to achieve a balanced state budget or its surplus and to reduce public debt more significantly. The government's original intention was to achieve a balanced state budget in 2017. This target was later delayed to 2019.

Table 1-Revenue and expenditure of the state budget of the Slovak Republic in mill.EUR (Source: made by the author according to the data: MFSR, 2020b)

\begin{tabular}{|l|c|c|c|c|c|c|c|c|}
\hline Year & 2012 & 2013 & 2014 & 2015 & 2016 & 2017 & 2018 & 2019 \\
\hline Revenue & 11830 & 12790 & 12497 & 16234 & 14277 & 14014 & 15381 & 15825 \\
\hline Expend. & 15641 & 14820 & 15420 & 18166 & 15256 & 15234 & 16563 & 18027 \\
\hline Balance & -3811 & -2023 & -2923 & -1933 & -980 & -1220 & -1182 & -2201 \\
\hline
\end{tabular}

Although the Slovak Republic has gradually reduced the government budget deficit (until 2018) in goods years of economic development, however, this remains. The most successful in this respect was 2016, when deficit reached its lowest level (EUR 980 million).

Paradoxically, the higher increase in the state budget deficit occurred in 2019, for which a balanced budget was originally planned. The reasons were both in the reduction in the rate of economic growth and, in particular, in the increase in government spending in the pre-election period. There has been a year-on-year increase in expenditure, particularly in relation to the valorization of salaries of civil and public servants, in the defense sector (purchase of aircraft and maintenance of equipment) and in the department of labor, social affairs and family (increase in existing and introduction of new social benefits). 


\section{DEVELOPMENT OF PUBLIC DEBT IN THE SLOVAK REPUBLIC}

Budget deficit increased significantly, by around EUR 1 milliard compared to 2018. Government has backed away from the intention of achieving a balanced budget in 2019 and 2020. Deficit in 2019 amounted to EUR 2.2 milliard, which is an increase of $86 \%$ compared to the previous year. State budget revenues increased by $2.9 \%$ year-to-year to around EUR 15.8 billion, including through higher tax collection. However, expenditure increased by 8.8\% to almost EUR 18.3 billion.

Table 2-General government balance in the Slovak Republic:deficit-to-GDP ratio (Source: made by the author according to the data: MFSR, 2020b)

\begin{tabular}{|l|c|c|c|c|c|c|c|c|}
\hline Year & 2012 & 2013 & 2014 & 2015 & 2016 & 2017 & 2018 & 2019 \\
\hline $\begin{array}{l}\text { Deficit: } \\
\text { \%GDP }\end{array}$ & $-4.3 \%$ & $-2.7 \%$ & $-3.1 \%$ & $-2.7 \%$ & $-2.5 \%$ & $-0.8 \%$ & $-0.7 \%$ & $-1.3 \%$ \\
\hline
\end{tabular}

2017 and 2018 were the only years when Slovakia managed that the general government deficit was less than $1 \%$ of GDP. In the years studied (except in 2012, when the aftermath crisis economic recovery was still only moderate), Slovakia was below 3\% of GDP by the level of the general government deficit, which corresponds to the Maastricht criterion.

\section{Development of public debt in the Slovak Republic}

The financial and economic crisis after 2007 has accelerated the indebtedness of most countries in the world. One of the main causes of the growth of public debts can be considered the method of setting economic policies before the financial crisis. Only a smaller group of developed countries have respected principles and rules for financial stability and their economies were thus not burdened by excessive debt. In most countries, however, economic growth was supported by an increase in government expenditure even in the expansionary phase of the economic cycle. Excessive loosening of fiscal policy occurred more frequently in the second half of the parliamentary term. At that time, the interest of government authorities is growing to increase the budget and to strengthen their hopes of regaining government position in election (Czesaný \& Johnson, 2012).

In order to ensure budgetary responsibility, a number of rules for the coordination of national fiscal and budgetary policies have been adopted in the European Economic and Monetary Union. The Stability and Growth Pact was approved in 1997 and entered into force on 1 January 1999 together with the introduction of the euro currency. The Stability and Growth Pact introduced a condition for guided economic policies in all countries so as to achieve balanced or surplus state budgets in the medium term. In the event of a deficit of more than $3 \%$ of GDP, member states should be penalized in the form of an interest-free deposit or a fine. The Pact's problem was its non-compliance. The condition of balanced or surplus budgets in the medium term, has not been respected by the must member states.

Following the outbreak of the debt crisis in the Euro area at the turn of 2009 and 2010, there was a need to adopt stricter fiscal and budgetary rules. Between 2011 and 2013, measures were adopted that reformed the economic pillar of the European Economic and Monetary Union, the rules were tightened, but this had led to less clarity and greater complexity (Dostálová, 2012). In December 2011, a package of six legal acts, five regulations and one directive entered into force, s. c. six-pack. It was aimed at limiting the fiscal irresponsibility and macroeconomic imbalances of countries. The measures taken as 
the most important appear to be the introduction of more automatic sanctions imposition processes and the introduction of penalties for the manipulation of statistical data.

Government of the Slovak Republic develops the Stability Program of the Slovak Republic every year (actually for the years 2018 to 2021) as a requirement of the Stability and Growth Pact. It is submitted annually to the European Commission and the Council of the EU. The Stability Program presents a budgetary strategy that should prevent the creation of an excessive deficit (or lead to its correction). It is necessary to ensure the long-term sustainability of public finances.

Table 3-Development of GDP and public debt in the Slovak Republic (years 2002-2007)

(Source: made by the author according to the data: Rozpočet SK, 2020)

\begin{tabular}{|l|c|c|c|c|c|c|}
\hline \multicolumn{1}{|c|}{ Year } & 2002 & 2003 & 2004 & 2005 & 2006 & 2007 \\
\hline $\begin{array}{l}\text { Public debt } \\
\text { (mill. EUR) }\end{array}$ & 16909 & 17937 & 19262 & 17535 & 17313 & 19167 \\
\hline $\begin{array}{l}\text { GDP (mill. EUR) } \\
\text { (current prices) }\end{array}$ & 37330 & 41479 & 46175 & 50486 & 56361 & 63163 \\
\hline $\begin{array}{l}\text { Public debt } \\
(\% \text { GDP) }\end{array}$ & $45,3 \%$ & $43,2 \%$ & $41,7 \%$ & $34,7 \%$ & $31,4 \%$ & $30,3 \%$ \\
\hline
\end{tabular}

Public debt from zero in 1993 amounted to 45.3\% of GDP in 2002. After the successful transformation of the Slovak economy from a centrally planned to a market economy and with gradual high economic growth, the share of public debt in GDP began to decrease. By 2008 , this share decreased to $28.6 \%$ of GDP. This positive trend of rapid economic growth (up to $10 \%$ in 2007) linked to the fall in public debt was halted by the economic recession that occurred in Slovakia as a result of the global financial and economic crisis. Public debt rose to $54.7 \%$ of GDP in 2013. Nevertheless, Slovakia is one of the countries with significantly lower public debt than the average of the European Union countries, which accounts for around $80 \%$ of GDP.

Table 4 - Development of GDP and public debt in the Slovak Republic (years 2008-2013)

(Source: made by the author according to the data: Rozpočet SK, 2020)

\begin{tabular}{|l|c|c|c|c|c|c|}
\hline \multicolumn{1}{|c|}{ Year } & 2008 & 2009 & 2010 & 2011 & 2012 & 2013 \\
\hline $\begin{array}{l}\text { Public debt } \\
\text { (mill. EUR) }\end{array}$ & 19616 & 23306 & 27910 & 30953 & 38031 & 40678 \\
\hline $\begin{array}{l}\text { GDP (mill. EUR) } \\
\text { (current prices) }\end{array}$ & 68591 & 64096 & 68093 & 71214 & 73484 & 74355 \\
\hline $\begin{array}{l}\text { Public debt } \\
(\% \text { GDP) }\end{array}$ & $28,6 \%$ & $36,4 \%$ & $41,0 \%$ & $43,5 \%$ & $51,8 \%$ & $54,7 \%$ \\
\hline
\end{tabular}

In the Slovak Republic, a constitutional law on budgetary responsibility was adopted, which sets out five bands of so-called debt brake (RRZ, 2019):

First band of debt brake: $49-52 \%$ of GDP.

Sanctions attached to this band constitute an obligation on the MF SR to justify to the National Council the amount of debt and propose measures to reduce it. The sanction shall apply until the amount of debt falls below the first limit.

Second band of debt brake: $52-54 \%$ of GDP. 


\section{DEVELOPMENT OF PUBLIC DEBT IN THE SLOVAK REPUBLIC}

There is a salaries freeze of the government members.

Third band of debt brake: $54-56 \%$ of GDP.

Means freezing/decrease of budget expenditure.

Fourth band of debt brake: 56-59\% of GDP.

A balanced/surplus state budget must be drawn up.

Fifth band of debt brake: above 59\% of GDP.

A vote of confidence in the government is declared.

In 2017, public debt amounted to 51.3\% of GDP and the first penalty band of the debt brake was applied because the debt ceiling is set at 49\% of GDP. The amount of gross debt in 2018 in the Slovak Republic was 49.4\% of GDP (RRZ, 2019). The government has set itself a target of reducing public debt by the end 2020 to $44.9 \%$ of GDP. This should help rapid growth of the economy, the recovery in price level growth and expected surpluses of primary management of general government. However, in 2019 there has been a slowdown in economic growth not only in the EU, but also in Slovakia. It was also a pre-election year, when government politicians tend to increase government spending to tilt the electorate. Nevertheless, debt has fallen to at least $48 \%$ of GDP and Slovakia went beyond the applicable penalty bands.

Table 5-Development of GDP and public debt in the Slovak Republic (years 2014-2019) (Source: made by the author according to the data: Rozpočet SK, 2020)

\begin{tabular}{|l|c|c|c|c|c|c|}
\hline \multicolumn{1}{|c|}{ Year } & 2014 & 2015 & 2016 & 2017 & 2018 & 2019 \\
\hline $\begin{array}{l}\text { Public debt } \\
\text { (mill. EUR) }\end{array}$ & 40802 & 41384 & 42160 & 43370 & 44322 & 45202 \\
\hline $\begin{array}{l}\text { GDP (mill. EUR) } \\
\text { (current prices) }\end{array}$ & 76256 & 79758 & 81038 & 84517 & 89721 & 94177 \\
\hline $\begin{array}{l}\text { Public debt } \\
\text { (\% GDP) }\end{array}$ & $53,5 \%$ & $51,9 \%$ & $52,0 \%$ & $51,3 \%$ & $49,4 \%$ & $48,0 \%$ \\
\hline
\end{tabular}

Share of public debt to GDP in the Slovak Republic decreased annually in the aftermath of the financial crisis. Nevertheless, the amount of public debt does not fall in absolute terms.

\section{Risks of development in the field of public finances in the Slovak Republic}

Approved general government budget for 2020 projected a deficit of 480.4 million EUR, representing $0.49 \%$ of GDP. Currently (July 2020), the general government budget deficit is estimated at $11.6 \%$ of GDP. This amounts, in absolute terms, a deficit of 10025.4 million EUR. Deficit will worsen by 11.09 percentage points. Estimation of the public finances development in 2020 is based on the current macroeconomic and tax forecast.

General government budget for 2020 predicted GDP growth of 2.3\% and the current estimation foresees a GDP slump of $9.8 \%$. Economic downturn causes decrease in the state budget revenue and will also increase the demands on government expenditure.

In July 2020, the National Council of the Slovak Republic adopted an amendment to the State Budget Act for 2020, which responds to the government's rescue measures taken in relation to the spread of contagious human disease COVID-19. The Slovak economy recorded in the first quarter of 2020 one of the largest GDP slumps in the EU. Public debt is 
expected to exceed $60 \%$ of GDP in 2020 and the general government deficit will increase to $8.5 \%$ of GDP.

\section{Conclusion}

Governments usually justify the setting up of deficit budgets and the increase in public debt by the need to stabilize the economy, in particular through fiscal policy. Both of these phenomena have become common in many developed and developing countries. The problem of excessive public debt can be addressed in several ways. One solution to the debt problem lies in fiscal consolidation, i.e. in reducing public expenditure or increasing public revenue, or using the privatization proceeds to pay the debt. However, in most countries, major spending reforms or tax increases are unpopular and politically difficult passable.

Since its inception in January 1993, the Slovak Republic has been managed permanently with deficit budgets. Public debt thus gradually increased from zero in 1993 to $54.7 \%$ of GDP in 2013. In the aftermath of the financial crisis (2014-2018), Slovakia achieved an average economic growth rate of $3.6 \%$.

These favorable times have not been sufficiently used for fiscal consolidation and to achieve the first ever balanced budget. The share of public debt to GDP has been decreased, but in absolute terms its volume is increasing. Economic growth contributed to keeping public debt at an acceptable level under debt brake rules.

This allowed reduce the share of public debt to GDP and gradually grow out of debt. To some extent, tax collection has improved, increasing the state budget revenues.

However, expenditure grew faster. GDP growth slowed in 2019, while the expenditure increased at the same time, which has been negatively reflected in the general government deficit. Global coronavirus pandemic makes the situation even more difficult, whereas Slovakia, as a small open economy focused on car production, depends largely on demand in foreign markets. It was a mistake that favorable economic times were not used better.

\section{Acknowledgement}

Article was developed in the framework of research project VEGA 1/0239/19 "Implications of behavioral economics to make the functioning of current economies more efficient".

\section{References}

Czesaný, S. \& Johnson, Z. (2012). Ekonomický cyklus, hospodářská politika a bohatsví zemí. Praha: Oeconomica.

Dostálová, I. (2012).Six-pack, two-pack, fiskální úmluva: cesta k fiskální odpovědnosti, nebo fiskální integraci? Sciencia et societas, 2, 20-42.

Karpiš, J. (2015). Zlé peniaze. Sprievodca krízou. Bratislava: INESS.

Krugman, P. (2012). End This Depression Now! New York: W.W. Norton \& Company.

Maxton, G. (2011). The End of Progress. How modern Economics Has Failed Us. New York: John Willey \& Sons Limited. 


\section{DEVELOPMENT OF PUBLIC DEBT IN THE SLOVAK REPUBLIC}

MFSR. (2020a). Rating zostáva výkričníkom. Retrieved on July 7, 2020: from http://mfsr.sk/sk/media/tlacove-spravy/rating-zostava-vykricnikom.html.

MFSR. (2020b). Štátny záverečný účet SR. Retrieved on July 12, 2020: from http://mfsr.sk/sk/financie/statne-vykaznictvo/statny-zaverecny-ucet-sr/\#collapse-5375.

Roubini, N. \& Mihm, S. (2013). Crisis Economics, a Crash Course in the Future of Finance. New York: Allen Lane.

Rothbard, M. N. (1993). Man, Economy, and State. - A Treatise on Economic Principles. Auburn: Ludwig Mises Institute.

Rozpočet SK. (2020). Štátny rozpočet SR. Retrieved on July 15, 2020: from http://rozpocet.sk/web/prehlad.

RRZ (2019). Správa o hodnoteni plnenia pravidiel rozpočtovej zodpovednosti a pravidiel rozpočtovej transparentnosti za rok 2019. (2020). Retrieved on July 20, 2020: from http://rozpoctovarada.sk/download2/hodnotenie_pravidiel_2019.pdf.

Schiller, B.R. (2004). Macroeconomie dnes. Brno: Computer Press.

Paper submitted

Paper accepted for publishing

Paper published online
O6 May 2020

O2 July 2020

31 July 2020 